\title{
Integration of social media into HRM practices: a bibliometric overview
}

\author{
Md Sajjad Hosain \\ Business School, Sichuan University, Chengdu, China
}

Received 6 December 2020

\begin{abstract}
Purpose - This paper aims to critically discuss the mounting role of social media (SM) or social networking sites (SNSs) on various human resource management (HRM) practices.

Design/methodology/approach - The paper is based on 87 published papers collected from the Web of Science Database particularly from 2010 to 2020 (up to June) using VOSviewer software. After reviewing those paper contents, the author briefly highlighted the findings.

Findings - According to most of the previous studies, the utilization of SM information for various HRM practices is rising although such utilization is mostly limited to talent search and recruitment \& selection at present. Further, it was found that Facebook and LinkedIn are the two most accepted sites among the hiring professionals where the first one mostly provides behavioral information and the second one provides jobrelated information. Finally, it was revealed that organizations can develop a strong corporate branding through the presence in SM.
\end{abstract}

Research limitations/implications - This review paper is expected to motivate further research initiatives regarding the role of social media into different HRM practices.

Practical implications - The author expects that based on the findings, the organizational policymakers can get some practical guidelines regarding the efficient utilization of such a platform.

Originality/value - Social media is a powerful platform for flourishing business entities, promoting products, branding, talent search and so many more purposes. An organization can well promote its existence through this popular platform. In particular, the media can be a well-established platform for searching competent employees and creating employer branding. Therefore, more and more research studies should be carried out focusing on this recent issue. This review paper can be a base for the upcoming researchers as it has accumulated the previous literature and their findings.

Keywords Human resource management, Social media, Social networking sites, Social media information, Hiring professionals, Job candidates

Paper type Literature review

\section{Introduction}

Because of recent faster changes in information technology, a rapid evolution has taken place in human resource management (HRM) practices. However, particularly since 2005, a new form of information sharing networks popularly known as social media (SM) has been

(C) Md Sajjad Hosain. Published in PSU Research Review. Published by Emerald Publishing Limited. This article is published under the Creative Commons Attribution (CC BY 4.0) licence. Anyone may reproduce, distribute, translate and create derivative works of this article (for both commercial and non-commercial purposes), subject to full attribution to the original publication and authors. The full terms of this licence maybe seen at http://creativecommons.org/licences/by/4.0/legalcode

Source of funding: There is no source of funding to be reported.

Conflict of interest: The author declares no conflict of interests.

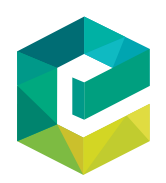

PSU Research Review Emerald Publishing Limited DOI 10.1108/PRR-12-2020-0039 
influencing the functions of HR professionals to a greater extent than before. Social media such as Facebook, LinkedIn, Twitter, Google+ and Xing have millions of users and the number is increasing at a good pace every year. A social networking site (SNS) is a special type of online social platform where the users can interact with each other through posting pictures, videos and comments, like and dislike; and share the contents. Although SM and SNS are being used interchangeably for one another by many authors, they have different particular meanings. SM is powered by web 2.0 that allows individual interactions with the aid of technological devices such as desktop, laptop and mobile phone indicating that SNSs, social shopping, social marketing, social gaming and social location tracking all are the components of SM (Haag, and Cummings, 2013). On the contrary, SNSs are the platforms through which people can create accounts, search and add new friends and share information contents (Haag and Cummings, 2013). The first SNS was introduced in 1997 known as Sixdegrees.com allowing the users to have an online personal profile and a record of acquaintances (Boyd, and Ellison, 2008).

A high level of activities by the individuals and organizations in SNSs is creating countless amount of information every day. Organizations are now using that information for serving their own purposes as resources. High availability, larger visibility, free of cost accessibility have made such information as the center of attraction not for only individuals but also a number of profit and non-profit organizations to discover. As an example, LinkedIn, a job-oriented SNS records all the professional information about a user, which can be viewed and used by the hiring professionals to attract competent future employees. An interesting fact is that, initially, such SNS information was never imagined to be used in businesses (Kluemper and Rosen, 2009).

The utilization of SNSs was primarily initiated through talent search and recruitment. However, at present, the use has not been limited to only that. Now-a-days, social media information (SMI) is being used by the HR departments for a number of functions such as attracting and acquiring (recruitment) talents, selection and pre-employment background checks, internal communication, training, on-boarding and team-building. The basic aim of this review paper is to critically discuss the role of SM on HRM with the evidence provided by the existing literature on how the organizations can ensure the optimum utilization of such big data for various HRM functions in the light of reviews and integration on the published literature obtainable from 2010 to June, 2020. After such an extensive review, the author has summarized the key research findings that he expects to aid future scholarly investigations and as practical guidelines for the HRM policymakers.

\section{Literature review}

As a result of the current and fast development of social media, scholastic investigations have been keeping a considerable adjustment with the growing organizational utilization of $\mathrm{SM}$. As a result, the readers and practitioners alike are enjoying abundant opportunities to connect them in scholastic exploration contained by a wide choice of areas where SM can be integrated with various HRM practices. New academic attention has indicated across a widespread choice of research disciplines within business as such marketing (Khan et al., 2019; AlAlwan et al., 2017; Ismagilova et al., 2017; Lister, 2017; Dwivedi et al., 2017, 2015; Kapoor et al., 2016; Lee et al., 2015; Goes et al., 2014; Goh et al., 2013; Dou et al., 2013; Labrecque et al., 2013; Luo, and Zhang, 2013; Baek et al., 2012; Chau, and Xu, 2012; Cheung et al., 2012; García-Crespo et al., 2010; Dellarocas et al., 2010), HRM (Hosain et al., 2020; Hosain and Liu, 2020; Becton et al., 2019; Carpentier et al., 2019; Jeske, and Shultz, 2019; Jeske et al., 2019; Suen, 2018; Carpentier et al., 2017; Marie-Cecile, and Pamela, 2017; El-Ouirdi et al., 2016; Hoek et al., 2016; Drake et al., 2016; Van-Iddekinge et al., 2016; Black et al., 2015; 
Lu et al., 2015; Jeske, and Shultz, 2015; Stoughton et al., 2015; Berkelaar, 2014; Nikolaou, 2014; Zide et al., 2014; Hauptmann, and Steger, 2013; Kluemper et al., 2012; Brown, and Vaughn, 2011; Madia, 2011; Clark, and Roberts, 2010), business strategy (Barrett et al., 2016; Cao et al., 2015; Dong, and Wu, 2015; Karoui et al., 2015), organizational psychology (Chen, and Sharma, 2015; McFarland and Ployhart, 2015; Butler, and Wang, 2012) and general business policies (Baur, 2017; Benthaus et al., 2016; Dennis et al., 2016; Bharati et al., 2014). Although the majority of the existing research have focused particularly on the role of SNSs on hiring decisions such as recruitment and selection and background checking of the prospective employees (Kluemper, 2013), this review paper will concentrate on the impact of social media on complete human resource management.

For a number of years, organizations have depended on the job sites such as Careerbuilder.com for recruiting employees, drawing the attraction of jobseekers out of around 100 other career sources. As per Nessler (2014), Careerbuilder.com has been able to effectively condense the expenditure for each hire by $70 \%$ as a result of reduced traveling expenses and by $60 \%$ time required by the recruiters in the employment process. Electronic recruitment can be defined as the adoption of web while recruiting job candidates (Melanthiou et al., 2015). With further development, recently, organizations have been attracted to use social media for different business purposes such as branding, recruitment $\&$ selection selection and background checking. As a result, many organizations now-a-days operate their organizational SM profile pages (such as Facebook and LinkedIn) for hiring job candidates (Melanthiou et al., 2015). For an instance, many organizations at present create and operate own organizational Facebook and LinkedIn profiles (pages) and using such SM pages as the means of advertisement tools in attracting and getting talents (Hosain and Liu, 2020; Andrews, 2012). Furthermore, there is a sharp enhancement in using SM by HR professionals or recruiters with the anticipation of finding "detailed and complicated job candidate information," and to evaluate and pick the best-matched job candidates (Brown and Vaughn, 2011). As per Facebook authority, it is going to introduce a novel attribute, which is expected to support organizations in directing their job advertisements (Take the Work out of Hiring, 2017). Additionally, as per the authorized Facebook webpage, job postings now can be linked to "Facebook Business Page" where the jobseekers can find and view the obtainable jobs with the help of "jobs bookmarks" on Facebook (Job posting on Facebook, n.d.). SM, therefore, is serving as a guide to promote followers (job seekers) toward organizational corporate websites where they are able to discover recent job postings (Spellmann, 2018). Therefore, with such a considerable number of account holders, hiring employees through SM provides the organizations a good scope of choices.

Prior studies termed Facebook and LinkedIn as the two most well-accepted social SM as the sources of hiring information (Melanthiou et al., 2015). As per the investigation conducted by society of human resource management (SHRM) on 541 hiring professionals, 95\% reported that they use LinkedIn as a hiring site whereas $58 \%$ revealed that they use Facebook and $42 \%$ of them reported to use Twitter (Zide et al., 2014). An inquiry intended to HR professionals in identifying the sort of technology they were using in their respective departments with relevant justification, concluded that technology such as web-based SM was becoming more prevalent in North America to hire job candidates particularly for medium-level positions (Villeda and McCamey, 2019). In addition, even though the interviewees revealed a higher number of job candidates, the superiority was possibly to continue to be unaffected or yet getting worse. However, such a utilization of SM for employment purposes differs in different regions or countries based on the accessibility to internet connection (and speed), as well as the use or reputation of different SNSs. As an example, $89 \%$ of the US people can access to the internet, $91 \%$ in Canada, $71 \%$ in the UK,
Social media into HRM practices 
$67 \%$ in Mexico, 39\% in Kenya and 25\% in India (Pew Research Center, 2018). Furthermore, as per same organization (Pew Research Center, 2018), people of more affluent countries such as US, The Netherlands, Germany, Sweden, Australia and Canada can enjoy a superior use of internet as opposed to the developing countries such as India, Tanzania, Indonesia, Bangladesh and Kenya. Therefore, based on such factors, the utilization of SM also varies in different counties, such as the US (69\%), Canada $(68 \%)$ and Russia $(66 \%)$ have a superior rate of SM utilization as opposed to India (20\%), Kenya (30\%) and Indonesia (26\%) (Pew Research Center, 2018). Nevertheless, during the latest years, the developing nations are also experiencing a swift augment in the utilization of the internet and SM. As, for example, such an utilization rose from $42 \%$ in 2013 to $64 \%$ in 2018 (regarding internet usage) and 34\% from 2013 to 53\% in 2018 (regarding SM usage) (Pew Research Center, 2018). Considering those statistical data regarding the utilization of SM/SNSs for employment purposes, it can be well-assumed that such utilization will show further upward trend in both in developed and developing counties alike.

There are a number of motives behind such increased utilization of SM for hiring practices. Among such motives, the first one is the cost and time saving benefit. Studies indicate that utilization of SNSs can lessen the expenses and time required for employment decisions through superior competence rates (Petre et al., 2016; Rosoiu and Popescu, 2016; Vidros et al., 2016). For an instance, introducing a job advert on the SM platform is almost free and such advertisement information can be modified if necessary or any error is noticed. On the contrary, an organization publishing a job advert in a newspaper or buying a web domain has to spend money. SM-based recruitment further permits the recruiters to have a considerable decrease in manual paper-based works that is environment friendly. On the other hand, such an SM advert removes or reduces the application costs for the jobseekers to a considerable extent (Petre et al., 2016). Second, SM can offer several hidden valuable information obtainable for the recruiters that may not be otherwise accessible somewhere else such as personality, behavioral prototype, hobbies, interests and types of friend networks (Hosain and Liu, 2020). In addition to those benefits mentioned, the hiring professionals can cross-examine any information that was previously supplied. Third, HR professionals often maintain business-oriented SNSs (such as LinkedIn) that provide plentiful information regarding inactive job candidates (Wolk, 2004). Those passive job seekers (not actively searching jobs but looking for better opportunities) are predominantly lucrative for any organization, as they usually hold an unemployed collection of competencies having not connected to job placement agencies or other hiring organizations (Hosain and Liu, 2020). A major portion of such candidates are thought as a particularly steady workforce (DeKay, 2009). He (DeKay, 2009) indicated that mass volume of LinkedIn profile holders generally look for having an opportunity to be contacted by recruiters for new job opportunities. The majority of LinkedIn profiles contain a comprehensive picture of current and previous work history, areas of skills and expertize; and links to networks accessible by previous supervisors and colleagues (Hosain and Liu, 2020). Fourth, many of the hiring professionals emphasize that they have firm accountability, being the organizational representatives and an important element of stakeholders to sustain the reputation of their organizations. Such an obligation is to avoid negligent hiring for they can be accused in the future. Hence, they should gain as much information as possible regarding the job candidate. Using the SM platform helps them to study as much information as they collect concerning possible future workforce. Furthermore, as they argue, they have their own right and a requirement in defending themselves from the accusations of neglectful hiring practices. Such an allegation might happen if they are "unsuccessful in revealing the applicants" "incompetencies or ineffectiveness" through a meticulous investigation of 
references, criminal background investigation or even common history (Clark and Roberts, 2010). Finally, such SM information can help the recruiters to have a likely match between person-job and/or person-organization. Many employers use SM information as a mean to assess applicants' behavior trends or distinctiveness (Stoughton et al., 2015), as similar information offer comparatively obvious and truthful individual personality traits like the contents posted on applicants' SNSs by their acquaintances, as opposed to the information on traditional curriculum vitae or/resumes, that is anticipated to calculate a specific notion or favorite image (Slovensky and Ross, 2012). Kluemper et al. (2012) carried out a couple of investigations on Facebook recognized that evaluating a job applicant's SNS page may as well provide practical information to predict the candidate's personality for an employment decision. Furthermore, SM information can be used to develop targeted job interview questions (Davison et al., 2011) and conversations and to construct acquaintances during interviews (Smith and Kidder, 2010).

Although having a great possibility to be used as an applicant screening platform, such utilization is not free of debate and confusion. Despite of having some obvious advantages, utilization of SMI for hiring is not free of risks or limitations whatever might be the word. Such practice carries some severe risks that can make an organization liable to the court if used improperly. Due to such limitations, some authors recommend not to use or use the SMI to a limited extent possible. First of all, many users and researchers alike argue that SNSs are not meant to be used for any official or organization-related issue. Those sites are purely created and meant for personal and social communication with some exceptions such as LinkedIn that was purely developed for professionals and job seekers. As a result, utilization of SM or SMI for the hiring process has become a matter of debate on the basis of ethical issues. A survey in the US discovered that one of the most common reasons for not short-listing or rejecting a job candidate was his/her "lifestyle" rather than employmentrelated information (Broughton et al., 2013). Yet again, 53\% of recruiters surveyed in the UK reported that they found SM content that influenced them not to hire a job candidate such as "provocative or inappropriate" photographs or information (CareerBuilder, 2016). One of the frequently cited ethical arguments against the use of SM profiles as part selection and screening process is that such search can allow for "unchecked" discrimination toward a candidate (Yarbrough, 2018). Clark and Roberts (2010) branded using SNSs for hiring as a socially irresponsible practice based on individual privacy breaches and violation of corporate social responsibilities of organizations. According to Lorenz and Kikkas (2014), several hiring are managers also facing ethical dilemmas regarding the decision of background search of candidates based on SM. However, it should be noted that such an ethical concern is almost absent or very unnoticeable for job-related SNS such as LinkedIn as the site is primarily intended for job search and sharing professional information where all the information are publicly available and nothing to hide on a personal basis. The concern is mainly regarding those SNSs that are regarded as the personal SNSs such as Facebook and Twitter. Therefore, as the issue of searching an applicant's SNS for hiring purposes is still in infancy but a growing practice, the employers need to make a proper balance between its advantages and ethical considerations.

Second, the utilization of SMI for hiring is giving birth to growing legal and privacy concerns as well. Every year, there is growing awareness and negative consequences regarding the utilization of freehand SM surfing for personal information. Such legal concern has forced to decide some employers not to search SNS for candidates' information. As an example, a survey conducted by SHRM in 2013 reported that the percentage of screening personal SNSs such as Facebook or Instagram to explore job candidates is $22 \%$, a decline from $34 \%$ in 2008 . The same survey attempted to identify the reasons for such 
decline where $74 \%$ of employers were reported to be concerned with legal risks or discovering information regarding protected characteristics at the time of perusing candidates' profiles, which can be a justifiable concern (Segal, 2014). One of the legal concerns might be the correctness of information obtained from SNS. An applicant employed on the basis of false or wrong information extracted from SM platforms can raise a lawful problem, arguing "defamation of character" (Broughton et al., 2013). Another issue might be legal privacy right, which is most probably to be founded on the "job-relevance of the information obtained" (Broughton et al., 2013). Additionally, organizations must respect their (job candidates') personal likeness and attitudes to the "real or perceived invasion of privacy" (Broughton et al., 2013). Moreover, additional lawful issues might contain potential favoritism at the time of using candidates' SMI. A single information concerning gender, race, age, faith or physical and/or mental disability obtained from SNSs and used as a condition of employing or not employing is branded as unlawful (Melanthiou et al., 2015). According to Broughton et al. (2013), if the recruiters try to obtain "too much" regarding candidates, they (recruiters) may use such information as the ground of personal favoritism and discrimination.

Finally, the most fatal risk that the hiring professionals typically undertake while searching and evaluating SMI is obtaining imprecise, forged or partial information (Slovensky, and Ross, 2012; Dennis, 2011; Elzweig, and Peeples, 2009). Information (contents) posted on SNS profiles may not be correct for a variety of causes. For instance, a profile might be fallacious or formed to reveal the profile holder show superior or inferior to the eyes of intended audience than he/she actually is depending on the objective (Johnson, 2011). To express in other words, persons may attempt to "fake good" or "fake bad" on their SNS profiles based on whom (target audience) they anticipate to showcase their information (Davison et al., 2011). Former research studies have established that the communal custom of most SNSs is to highlight overstatement and eccentric actions while posted by job candidates might reveal such standards (Davison et al., 2011). SMI might as well be obsolete and can symbolize what applicants were similar to in diverse stages of their lives and might or might not symbolize what they actually like today (Davison et al., 2011). Therefore, the information that required today might be misleading for the employers who want to rely on such information for pre-employment background check (PBC). Depending excessively on the information obtained from SNSs might result in unfair inferences due to the possibility of intentional or unintentional inaccuracy (Waring and Buchanan, 2010). The usability of such information will be legally and ethically questionable and might require more study to conduct (Davison et al., 2011).

\section{Research method and materials}

The author used VOSviewer software for making a bibliometric mapping to search published papers based on citation, co-citation, bibliometric coupling, frequently used keywords and co-authorship networks. To find the relevant papers, the author used the database of Web of Science (WoS). The reason for choosing only WoS database for this review paper is that it is the proper and authentic source of published papers with reliable impact factors. Papers published focusing on the role or impact of social media or SNSs on various HRM practices were a matter of interest. The author included particularly the papers published from 2010 to June, 2020.

Following the preliminary exploration with the similar or related keywords, 211 papers were identified. It should be noted that the author considered only published papers (online and print both) for this review article (not conference papers, books, book chapters or published thesis). After removing those papers published before 2010 and after June, 2020 or 
not relevant to the searching interest, the number of papers finally stood to 87 (Figure 1). After that, the author went through the title, abstracts and keywords.

In the subsequent step, bibliometric data were downloaded from the WoS database and analyzed using MS Excel and VOSviewer software. Particularly, a universal overview of the bibliographic information was analyzed using MS Excel and visualizing leading networks and clusters were formed by VOSviewer software (Rahman et al., 2020; Paltrinieri et al., 2019; Fellnhofer, 2019). Because of the scaling and algorithm techniques engaged in these tools, VOSviewer has been acknowledged as a more powerful tool compared to others for bibliometric analysis of publications and literature (Waltman and van Eck, 2013). VOSviewer powerfully identifies the associated publications based on reference cited in two documents provided that interconnected reference cited in two publications is considered as a common school of thought and positioned closely on the visual map (van Eck and Waltman, 2014). Therefore, publications not linked to the social media and HRM practices were discarded during mapping analysis. Finally, after deducting the irrelevant papers manually, the process yielded 87 published papers and was grouped into 4 clusters with the default setting in VOSviewer (Tables 1 to 4 ).

As noted earlier, after filtering, the author went through the abstracts and keywords. After that, he summarized the contents based on abstracts. However, due to the high volume of papers, only the paper titles, journals names with volume and issue number have been highlighted in the following Tables 1-4. The papers have been presented based on the role of SM on different HRM practices and according to the most recent year first.

It is evident that, according to the contents and keywords provided, most of those published papers concentrated their focus on the recruitment and selection segment of HRM only while other HRM practices have not got the adequate attention of the researchers. Further, most of the published papers are based on the Western scenario.

\section{Findings in brief}

After reviewing all the 87 papers, the author made an attempt to elicit the major findings that are highlighted in this section.
Social media into HRM practices

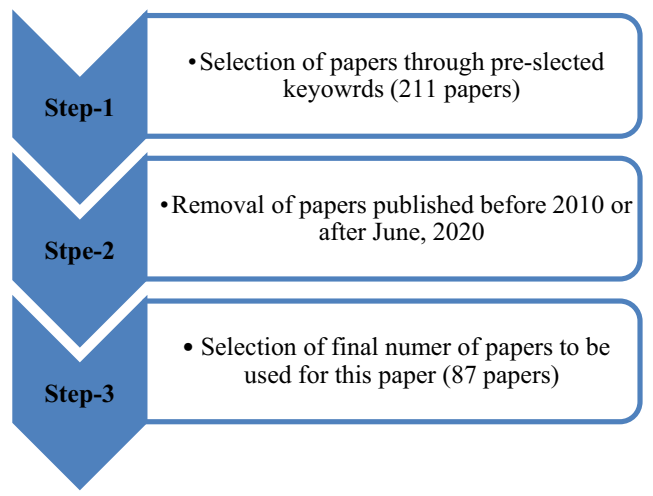

Source: Author's elaboration
Figure 1.

Selection process of papers 
Author(s) and

year of

Paper title

The impact of social media recruitment on job candidates' perceptions: evidence from

Bangladeshi fresh graduates

Social media recruitment: the role of

credibility and satisfaction

Social media recruitment: communication

characteristics and gratifications

Social media screening and content effects:

implications for job applicant reactions

Predicting self-disclosure in recruitment in

the context of social media screening

LinkedIn as a new selection method:

psychometric properties and assessment

approach

Use of social networking sites for recruiting

and selecting in the hiring process

Digital “women's work?”: job recruitment ads

and the feminization of social media

employment

Understanding the recruitment and selection

processes of management accountants: an

explorative study

Marketing video-enabled social media as part

of your e-recruitment strategy: stop trying to be trendy

Social media recruitment 3.0: toward a new paradigm of strategic recruitment

communication

A multi-model recruitment strategy using social media and internet-mediated methods to recruit a multidisciplinary, international sample of clinicians to an online research study

How passive job candidates respond to social networking site screening

The impact of social media on recruitment:

are you LinkedIn?

The role of the internet and social networks in the recruitment and selection process

Getting a job via career-oriented social

networking markets

Applicant perspectives during selection: a review addressing so What? "What is new?" and "where to next?"

Interpersonal perception of LinkedIn profiles and employability

Table 1.

Facebook profile picture appearance affects

The role of SM/SNSs recruiters' first hiring decisions

Agneš et al. publication

Journal name with volume and issue

Hosain and Liu

(2020)

Muduli and

Trivedi (2020)

Carpentier et al.

(2019)

Jeske and Shultz

(2019)

Postmodern Openings, 11(1)

Jeske et al. (2019)

Roulin and

Evidence-based HRM, 8(2)

Frontiers in Psychology, 10(7)

International Journal of Manpower, 40

(1)

Levashina (2018)

Villeda and

McCamey (2019)

Duffy and

Schwartz (2018)

Lepistö and

Ihantola (2018)

Employee Responsibilities and Rights

Journal, 31

Personnel Psychology, 72(2)

International Business Research, 12(3)

New Media and Society, 20(8)

Esch and Mente

(2018)

Aggerholm and

Andersen (2018)

McRobert et al.

(2018)

Qualitative Research in Accounting and

Management, 15(1)

Journal of Retailing and Consumer

Services, 44

Journal of Communication

Management, 22(2)

PLoS ONE 13(7)

Suen (2018)

Computers in Human Behavior, 85

Koch et al. (2018) SA Journal of Human Resource

Management, 16(1)

Strategic Management, 22(3)

(2017)

Buettner (2017)

Electron Markets, 27

McCarthy et al.

(2017)

Journal of Management, 43

Ramon et al.

(2017)

Aloma: Journal of Psychology,

Baert (2017)

New Media and Society, 20(3)

(continued) 


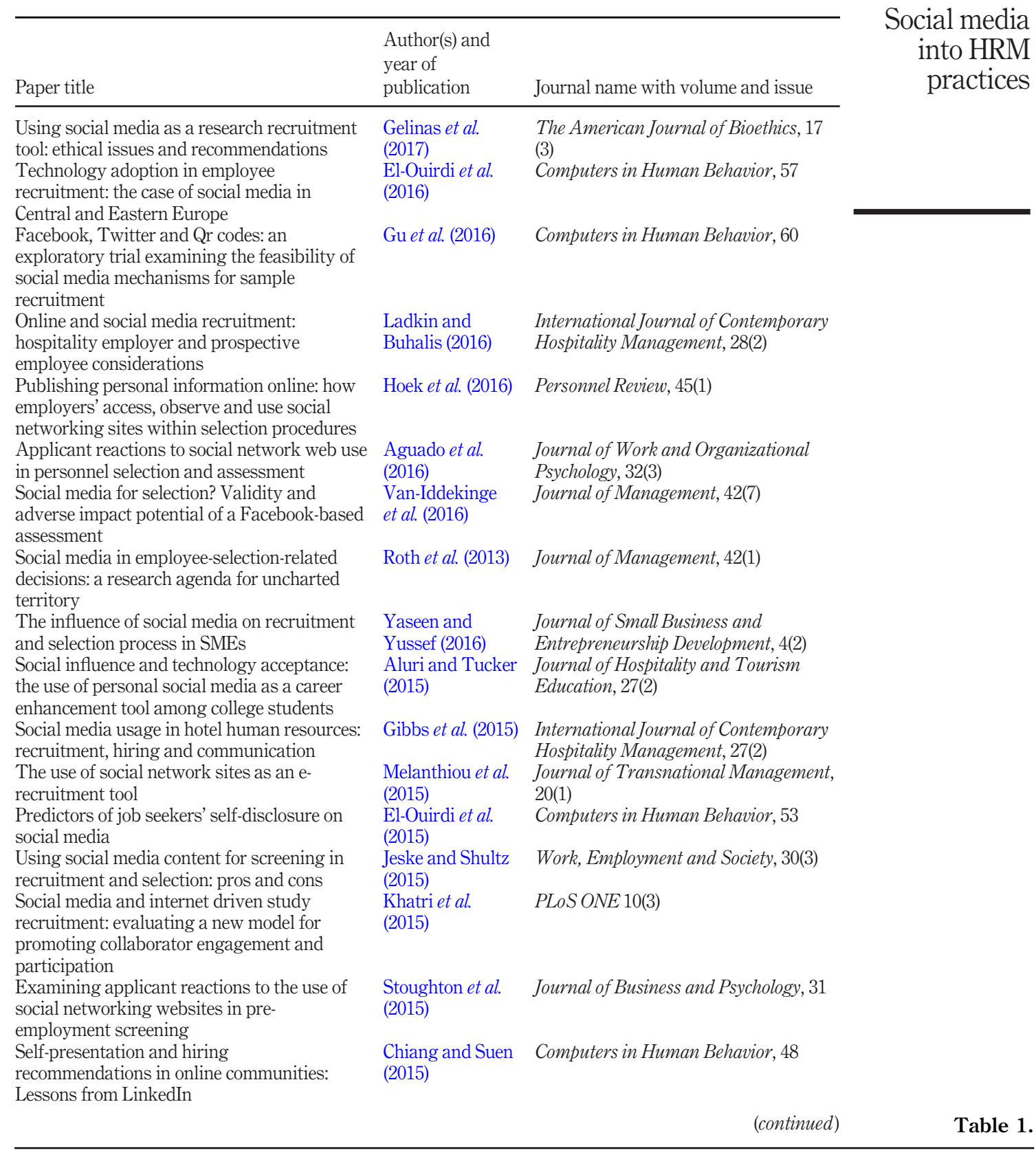


Author(s) and

year of

Paper title

publication

Cybervetting, online information and personnel selection: new transparency expectations and the emergence of a digital social contract

Leveraging social media to enhance recruitment effectiveness: a Facebook experiment

Social media recruitment and online data collection: a beginner's guide and best practices for accessing low-prevalence and hard-to-reach populations

LinkedIn and recruitment: how profiles differ across occupations

Information from social networking sites: Context collapse and ambiguity in hiring process

Social networking web sites in job search and employee recruitment

Social networking sites and hiring: How social media profiles influence hiring decisions

Social networking websites in personnel selection: a signaling perspective on recruiters' and applicants' perceptions Social media in employee selection-related decisions: a research agenda for uncharted territory

Online social networks: an emergent recruiter tool for attracting and screening

Should human resource managers use social media to screen of job applicants: managerial and legal issues in the USA

Using social networking sites as a selection tool: the role of selection process fairness and job pursuit intentions

The writing on the (Facebook) wall: the use of social networking sites in hiring decisions Legal implications of employee social media use

Best practices for using social media as a recruitment strategy

LinkedIn and Facebook in Belgium: the influences and biases of social network sites in recruitment and selection procedures
Berkelaar (2014) $\begin{aligned} & \text { Management Communication } \\ & \text { Quarterly, 28(4) }\end{aligned}$ Quarterly, 28(4)

Carrillat et al. Internet Research, 24(4)

(2014)

King et al. (2014) Canadian Psychology/Psychologie

Canadienne, 55(4)

Zide et al. (2014) Employee Relations, 36(5)

Pike et al. (2014) Information Systems Journal, 28

Nikolaou (2014) International Journal of Selection and

Assessment, 22(2)

Sameen and Journal of Business Studies Quarterly, 7(1)

Cornelius (2013)

Roulin and Personnel Psychology, 12(3)

Bangerter (2013)

Roth et al. (2013) Journal of Management, 20(10)

Ollington et al. Personnel Review, 42(3)

(2013)

Slovensky and Info, 14(1)

Ross (2012)

Madera (2012)

International Journal of Hospitality Management, 31(4)

Brown and

Vaughn (2011)

Dennis (2011)

Journal of Business Psychology, 26

Massachusetts Law Review, 93(4)

Madia (2011)

Strategic HR Review, 10(6)

Caers and

Castelyns (2010)

Social Science Computer Review, 29(4)

Table 1.

Source: Literature survey

\subsection{Job-oriented and social/communicative social networking sites}

SNSs are divided into two categories. The first one is professional (such as LinkedIn) while the other ones are purely social and communicative (Hosain, and Liu, 2020; Muduli, and Trivedi, 2020; Jeske et al., 2019; Villeda, and McCamey, 2019; Koch et al., 2018; Gelinas et al., 


\begin{tabular}{|c|c|c|c|}
\hline Paper title & $\begin{array}{l}\text { Author(s) and year of } \\
\text { publication }\end{array}$ & $\begin{array}{l}\text { Journal name with volume and } \\
\text { issue }\end{array}$ & $\begin{array}{l}\text { social media } \\
\text { into HRM }\end{array}$ \\
\hline $\begin{array}{l}\text { Social networking information and pre- } \\
\text { employment background checks: the } \\
\text { mediating role of sustainable } \\
\text { organizational reputation }\end{array}$ & Hosain et al. (2020) & Sustainability, 12(8) & \\
\hline $\begin{array}{l}\text { Job applicants' information privacy } \\
\text { protection responses: using social media } \\
\text { for candidate screening }\end{array}$ & Drake et al. (2016) & $\begin{array}{l}\text { Transactions in Human } \\
\text { Computer Interactions, } 8(4)\end{array}$ & \\
\hline $\begin{array}{l}\text { Perceptions of employees on information } \\
\text { checks by employers using social } \\
\text { networking sites in IT sector }\end{array}$ & $\begin{array}{l}\text { Tripathy and Kaur } \\
\text { (2012) }\end{array}$ & $\begin{array}{l}\text { Management and Labor } \\
\text { Studies 37(4) }\end{array}$ & \\
\hline $\begin{array}{l}\text { Candidate screening, information } \\
\text { technology and the law: social media } \\
\text { considerations }\end{array}$ & Willey et al. (2012) & $\begin{array}{l}\text { Issues in Information Systems, } \\
13(1)\end{array}$ & \\
\hline $\begin{array}{l}\text { Social networking websites, personality } \\
\text { ratings and the organizational context: } \\
\text { more than meets the eye? }\end{array}$ & Kluemper et al. (2012) & $\begin{array}{l}\text { Journal of Applied Social } \\
\text { Psychology, } 42(5)\end{array}$ & $\begin{array}{r}\text { Table } 2 . \\
\text { The role of SM/SNSs }\end{array}$ \\
\hline $\begin{array}{l}\text { The influence of social networking web } \\
\text { sites on the evaluation of job candidates }\end{array}$ & $\begin{array}{l}\text { Bohnert and Ross } \\
\text { (2010) }\end{array}$ & $\begin{array}{l}\text { Cyberpsychology, Behavior and } \\
\text { Social Networking, } 13(3)\end{array}$ & $\begin{array}{r}\text { on pre-selection } \\
\text { screening and } \\
\text { background check: } 6\end{array}$ \\
\hline Source: Literature survey & & & papers \\
\hline
\end{tabular}

\begin{tabular}{|c|c|c|c|}
\hline Paper title & $\begin{array}{l}\text { Author(s) and year of } \\
\text { publication }\end{array}$ & $\begin{array}{l}\text { Journal name with volume and } \\
\text { issue }\end{array}$ & \\
\hline $\begin{array}{l}\text { Attracting applicants through the organization's } \\
\text { social media page: signaling employer brand } \\
\text { personality }\end{array}$ & $\begin{array}{l}\text { Carpentier et al. } \\
\text { (2019) }\end{array}$ & $\begin{array}{l}\text { Journal of Vocational } \\
\text { Behavior, } 115\end{array}$ & \\
\hline $\begin{array}{l}\text { Extending the boundaries of corporate } \\
\text { branding: an exploratory study of the influence } \\
\text { of brand familiarity in recruitment practices } \\
\text { through social media by B2B firms }\end{array}$ & $\begin{array}{l}\text { Kumar and Möller } \\
\text { (2018) }\end{array}$ & $\begin{array}{l}\text { Corporate Reputation } \\
\text { Review, } 21\end{array}$ & \\
\hline $\begin{array}{l}\text { Employer branding on social media and } \\
\text { recruitment websites: symbolic traits of an ideal } \\
\text { employer }\end{array}$ & Ludvík et al. (2018) & $\begin{array}{l}\text { E+MEkonomie a } \\
\text { Management, 21(1) }\end{array}$ & \\
\hline $\begin{array}{l}\text { Recruiting nurses through social media: effects } \\
\text { on employer brand and attractiveness }\end{array}$ & $\begin{array}{l}\text { Carpentier et al. } \\
(2017)\end{array}$ & $\begin{array}{l}\text { Journal of Advanced Nursing, } \\
73(11)\end{array}$ & \\
\hline $\begin{array}{l}\text { Employer attractiveness through social media: a } \\
\text { phenomenological study }\end{array}$ & $\begin{array}{l}\text { Priyadarshini et al. } \\
\text { (2017) }\end{array}$ & The Qualitative Report, 22(4) & \\
\hline $\begin{array}{l}\text { Employer brand scale development and } \\
\text { validation: a second-order factor approach }\end{array}$ & $\begin{array}{l}\text { Tanwar, and Prasad } \\
\text { (2017) }\end{array}$ & Personnel Review, 46(2) & \\
\hline $\begin{array}{l}\text { Using social media to communicate employer } \\
\text { brand identity: the impact on corporate image } \\
\text { and employer attractiveness }\end{array}$ & $\begin{array}{l}\text { Kissel and Büttgen } \\
\text { (2015) }\end{array}$ & $\begin{array}{l}\text { Journal of Brand } \\
\text { Management, } 22\end{array}$ & \\
\hline $\begin{array}{l}\text { Employer brand and job application decisions: } \\
\text { insights from the best employers }\end{array}$ & Saini et al. (2015) & $\begin{array}{l}\text { Management and Labor } \\
\text { Studies, } 40(1-2)\end{array}$ & \\
\hline $\begin{array}{l}\text { Employer branding: strategy for improving } \\
\text { employer attractiveness }\end{array}$ & $\begin{array}{l}\text { Leekha and Sharma } \\
\text { (2014) }\end{array}$ & $\begin{array}{l}\text { International Journal of } \\
\text { Organizational Analysis, 22(1) }\end{array}$ & \\
\hline $\begin{array}{l}\text { Employer branding: employer attractiveness } \\
\text { and the use of social media }\end{array}$ & Sivertzen et al. (2013) & $\begin{array}{l}\text { Journal of Product and Brand } \\
\text { Management, } 22(7)\end{array}$ & $\begin{array}{r}\text { Table } 3 . \\
\text { The role of SM/SNSs } \\
\text { on employer }\end{array}$ \\
\hline Source: Literature survey & & & branding: 10 papers \\
\hline
\end{tabular}


Author(s) and

year of

Paper title

publication

Becton et al.

(2019)

Investigating the relationship between

social media content and

counterproductive work behaviors,

alcohol consumption and episodic heavy drinking

Social media, open innovation and HRM:

implications for performance

When employees do not "like" their

employers on social media

Enterprise social networks: a literature

review and research agenda

Storying the digital professional: how

online screening shifts the primary site

and authorship of workers' career stories

Use of social media at work: a new form of employee voice?

Enterprise social media at work: web-

based solutions for employee engagement

Use of social networking websites on

applicants' privacy

Social networking, management

responsibilities and employee rights: the

evolving role of social networking in

employment decisions

Who is responsible for what? Examining

strategic roles in social media

management

Who has Googled whom? Trainees'

internet and online social networking

experiences, behaviors and attitudes with

clients and supervisors

Social networking and HRD

A brave new (digital) world? Effects of inhouse social media on HRM

HRD practices and talent management in the companies with the employer brand

Friend or foe? The promise and pitfalls of using social networking sites for $\mathrm{HR}$

decisions

Social media in the workplace-proactive protections for employers

Online social networking and trade union

membership: what the Facebook

phenomenon truly means for labor

organizations

Employer's use of social networking sites:

Table 4.

a socially irresponsible practice

The role of SM/SNSs on other HRM

practices: 19 papers
You have been tagged! (then again, maybe not): employers and Facebook

Source: Literature survey

\author{
de Zubielqui et al. Technological Forecasting and Social \\ (2017) \\ Marie-Cecile and \\ Pamela (2017) \\ Wehner et al. \\ (2017) \\ $\begin{array}{ll}\text { Berkelaar et al. } & \text { Journal of Applied Communication } \\ \text { (2016) } & \text { Research, 44(3) }\end{array}$ \\ (2016) \\ Holland et al. \\ (2016) \\ Sharma and \\ Bhatnagar (2016) \\ Black et al. (2015) \\ Thomas et al. \\ (2015) \\ Change, 144 \\ MIT Sloan Management Review, 58(2) \\ Computer Networks, 114 \\ International Journal of Human \\ Resource Management, 27(21) \\ Human Resource Management \\ International Digest, 24(7) \\ Employment Responsibilities and Rights \\ Journals, 27 \\ Employment Responsibilities and Rights \\ Journals, 27
}

Neill and Moody

(2015)

Penelope and

Ashwini (2014)

Roberts and

Sambrook (2014)

Hauptmann and

Steger (2013)

Kucherov and

Zavyalova (2012)

Davison et al.

(2011)

Lieber (2011)

Bryson et al.

(2010)

Clark and

Roberts (2010)

Smith and

Kidder (2010)
Employment Relations Today, 38(3)

Labor History, 51(1)

Public Relations Review, 41

Training and Education in Professional Psychology, 8(2)

Human Resource Development

International, 17(5)

German Journal of Human Resource

Management, 27(1)

European Journal of Training and

Development, 36(1)

Journal of Business Psychology, 26

Business Horizons, 53
Journal of Business Ethics, 95 
2017; Roth et al., 2013; Slovensky, and Ross, 2012; Dennis, 2011). While the first one was developed and meant as the platform for professionals, employers and job seekers, the second category was meant to communicate among the online friends where the users post personal and social contents.

\subsection{Utilization of social media/social networking sites for talent search, recruitment and selection}

So far, the utilization of SM/SNSs is mostly limited to talent search, recruitment and selection (Hosain, and Liu, 2020; Villeda, and McCamey, 2019; Suen, 2018; Agneš et al., 2017; Melanthiou et al., 2015; Jeske and Shultz, 2019; Zide et al., 2014; Slovensky, and Ross, 2012; Brown, and Vaughn, 2011).

\subsection{Social media/social networking sites for employer branding}

According to numerous research studies, SM/SNSs can help employers in boosting up their brand and reputation (Carpentier et al., 2019; Priyadarshini et al., 2017; Kissel, and Büttgen, 2015; Sivertzen et al., 2013). Such branding is possible taking the advantages of both professional and non-professional SNSs depending on the popularity.

\subsection{Legal and ethical concerns in using social media information for hiring decisions}

A large number of users of SM/SNSs are concerned about the use of their SMI for hiring decisions. Such concerns are particularly concentrated around the ethics and privacy issues (Marie-Cecile and Pamela, 2017; Black et al., 2015; Thomas et al., 2015; Clark, and Roberts, 2010). On the other hand, many hiring managers are particularly concerned about the legal issues in using such SNSs information (Dennis, 2011).

\subsection{Collection of job-related and behavioral information}

The employers can accumulate some job-related (Roulin, and Levashina, 2018; Koch et al., 2018; Priyadarshini et al., 2017; Chiang, and Suen, 2015; Zide et al., 2014; Caers, and Castelyns, 2010) and behavioral information (Jeske and Shultz, 2019; Jeske et al., 2019; Baert, 2017; Sameen and Cornelius, 2013; Kluemper et al., 2012; Willey et al., 2012) from different SNSs. Such information can help them to determine job-fit and organization-fit.

\subsection{Using social media information is a growing practice}

Finally, according to the statistical data and research evidence, despite some criticisms and concerns, the utilization of SMI for various HR practices is a growing practice in many parts of the world.

\section{Theoretical and practical implications}

SM has been able to gain a swift notice from the academic scholars and researchers although we observe a strong lack of evidences (both theoretical and empirical) on how to, when to and which information to use for various HRM-related activities. This extensive review of previous literature has summarized and highlighted the findings of those studies briefly. The author is optimistic that this review paper will aid the academicians to make additional investigation regarding this comparatively recent but growing area more deeply and with wider scope. Therefore, this extensive review can bridge the gap of adequate research absence to some extent, as this part of organizational management desires additional concentration and outcome to be documented within the academic scope. 
This review paper is expected to be supportive to the hiring organizations and decisionmakers to formulate and execute their organizational HRM policies in using SMI. Social media is an accepted platform that may be used to save valuable time and financial resources on the condition that it is being used with utmost care having appropriate guiding procedures to evade further complicacies. Most importantly, this review paper may act as an essential guidance in crafting and executing an appropriate social media policy to make sensible and competent exploitation of SMI for different HRM practices.

\section{Conclusion}

Being the foreseeable component of technical improvement and expansion none can disregard social media or SNSs as part of our routine and/or strategic organizational functions. However, early security measures must be taken whilst using such a network maintaining uniformity with existing local and international legal guidelines and conventions. Additionally, the involved parties in this issue of interest, employers and employees (including job candidates) ought to respect one another regarding the terms of privacy, equality \& morals (for employers) and managerial policies \& regulations (for employees). Utilization of SMI can merely be successful and competent provided that together the employers and employees are well-concerned of the fundamental lawful and ethical basics regarding the latest utilizations in fulfilling organizational and business objectives.

It is understandable that social media being extensively used in different HRM practices particularly for talent search and acquisition and such practices are expected to rise as an aiding instrument for different organizations in the forthcoming years. Nevertheless, using SMI exclusively in place of the conventional methods can be challenging. Furthermore, using SM as an instrument for HRM functions may lead to legal problems as well. Likewise, SNSs well include many non-work-related (private or social contents) components that can create biased decision-making, particularly in recruitment and selection decisions. Finally, the author argues using such platform as an assisting tool for HRM practices is a rapidly burgeoning practice, although the utilization of SM on HRM is severely an under-researched area. The author hopes this elaborate review will put the base for potential theoretical and empirical research investigations concerning this particular issue.

\section{References}

Aggerholm, H.K. and Andersen, S.E. (2018), "Social media recruitment 3.0: toward a new paradigm of strategic recruitment communication", Journal of Communication Management, Vol. 22 No. 2, pp. 122-137.

Agneš, S., Radmila, B. and Nemanja, B. (2017), "The role of the internet and social networks in recruitment and selection process", Strategic Management, Vol. 22 No. 3, pp. 36-43.

Aguado, D., Rico, R., Rubio, V.J. and Fernandez, L. (2016), "Applicant reactions to social network web use in personnel selection and assessment", Journal of Work and Organizational Psychology, Vol. 32 No. 3, pp. 183-190.

AlAlwan, A., Rana, N.P., Dwivedi, Y.K. and Algharabat, R. (2017), "Social media in marketing: a review and analysis of the existing literature”, Telematics and Informatics, Vol. 34 No. 7, pp. 1177-1190, available at: www.sciencedirect.com/science/article/pii/S0736585317301077 (accesses 21 July 2020).

Aluri, A. and Tucker, E. (2015), "Social influence and technology acceptance: the use of personal social media as a career enhancement tool among college students", Journal of Hospitality and Tourism Education, Vol. 27 No. 2, pp. 48-59. 
Andrews, C. (2012), “Social media recruitment”, Applied Clinical Trials, Vol. 21 No. 11, p. 32.

Baek, H., Ahn, J. and Choi, Y. (2012), "Helpfulness of online consumer reviews: readers' objectives and review cues", International Journal of Electronic Commerce, Vol. 17 No. 2, pp. 99-126.

Baert, S. (2017), "Facebook profile picture appearance affects recruiters' first hiring decisions", New Media and Society, Vol. 20 No. 3, pp. 1220-1239.

Barrett, M., Oborn, E. and Orlikowski, W. (2016), "Creating value in online communities: the sociomaterial configuring of strategy, platform, and stakeholder engagement", Information Systems Research, Vol. 27 No. 4, pp. 704-723.

Baur, A.W. (2017), "Harnessing the social web to enhance insights into people's opinions in business, government and public administration”, Information Systems Frontiers, Vol. 19 No. 2, pp. 231-251.

Becton, J.B., Walker, H.J., Schwager, P. and Gilstrap, J.B. (2019), "Is what you see what you get? Investigating the relationship between social media content and counterproductive work behaviors, alcohol consumption, and episodic heavy drinking", The International Journal of Human Resource Management, Vol. 30 No. 15, pp. 2251-2272.

Benthaus, J., Risius, M. and Beck, R. (2016), "Social media management strategies for organizational impression management and their effect on public perception", The Journal of Strategic Information Systems, Vol. 25 No. 2, pp. 127-139.

Berkelaar, B.L. (2014), "Cybervetting, online information, and personnel selection: new transparency expectations and the emergence of a digital social contract", Management Communication Quarterly, Vol. 28 No. 4, pp. 479-506.

Berkelaar, B.L., Birdsell, J.L. and Scacco, J.M. (2016), "Storying the digital professional: how online screening shifts the primary site and authorship of workers' career stories", Journal of Applied Communication Research, Vol. 44 No. 3, pp. 275-295.

Bharati, P., Zhang, C. and Chaudhury, A. (2014), "Social media assimilation in firms: investigating the roles of absorptive capacity and institutional pressures", Information Systems Frontiers, Vol. 16 No. 2, pp. 257-272.

Black, S.L., Stone, D.L. and Johnson, A.F. (2015), “Use of social networking websites on applicants' privacy”, Employee Responsibilities and Rights Journal, Vol. 27 No. 2, pp. 115-159.

Bohnert, D. and Ross, W.H. (2010), "The influence of social networking web sites on the evaluation of job candidates", Cyberpsychology, Behavior and Social Networking, Vol. 13 No. 3, pp. 341-347.

Boyd, D.M. and Ellison, N.B. (2008), "Social network sites: definition, history, and scholarship”, Journal of Computer-Mediated Communication, Vol. 13 No. 1, pp. 210-230.

Broughton, A., Foley, B., Lendermaier, S. and Cox, A. (2013), "The use of social media in the recruitment process", The Institute for Employment Studies, 11, 1-81, available at: www.acas.org.uk/media/ pdf/0/b/The-use-of-social-media-in-the-recruitmentprocess.pdf. (accessed 25 July 2020).

Brown, V.R. and Vaughn, E.D. (2011), "The writing on the (facebook) wall: the use of social networking sites in hiring decisions", Journal of Business and Psychology, Vol. 26 No. 2, pp. 2-19.

Bryson, A., Gomez, R. and Willman, P. (2010), "Online social networking and trade union membership: what the facebook phenomenon truly means for labor organizations", Labor History, Vol. 51 No. 1, pp. 41-53.

Buettner, R. (2017), "Getting a job via career-oriented social networking markets”, Electronic Markets, Vol. 27 No. 4, pp. 371-385.

Butler, B.S. and Wang, X. (2012), "The cross-purposes of cross-posting: boundary reshaping behavior in online discussion communities", Information Systems Research, Vol. 23 No. 3-part-2, pp. 993-1010.

Caers, R. and Castelyns, V. (2010), "LinkedIn and Facebook in Belgium: the influences and biases of social network sites in recruitment and selection procedures", Social Science Computer Review, Vol. 29 No. 4, pp. 437-448. 
Cao, X., Guo, X., Liu, H. and Gu, J. (2015), “The role of social media in supporting knowledge integration: a social capital analysis", Information Systems Frontiers, Vol. 17 No. 2, pp. 351-362.

CareerBuilder (2016), "Number of employers using social media to screen candidates has increased $500 \%$ over the last decade", available at: http://bit.ly/2pfxAnR (accessed 25 June 2020).

Carpentier, M., Hoye, G.V. and Weijters, B. (2019), “Attracting applicants through the organization's social media page: signaling employer brand personality", Journal of Vocational Behavior, Vol. 115, pp. 211-223.

Carpentier, M., Hoye, G.V. and Wend, Q. (2019), "Social media recruitment: communication characteristics and gratifications", Frontiers in Psychology, Vol. 10 No. 7, pp. 1-12.

Carpentier, M., Hoye, G.V., Stockman, S., Schollaert, E., Theemsche, B.V. and Gerd, J. (2017), "Recruiting nurses through social media: effects on employer brand and attractiveness", Journal of Advanced Nursing, Vol. 73 No. 11, pp. 2696-2708.

Carrillat, A.F., d'Astous, A. and Morissette, G.E. (2014), "Leveraging social media to enhance recruitment effectiveness: a Facebook experiment", Internet Research, Vol. 24 No. 4, pp. 474-495.

Chau, M. and Xu, J. (2012), "Business intelligence in blogs: understanding consumer interactions and communities", MIS Quarterly, Vol. 36 No. 4, pp. 1189-1216.

Chen, R. and Sharma, S.K. (2015), "Learning and self-disclosure behavior on social networking sites: the case of Facebook users”, European Journal of Information Systems, Vol. 24 No. 1, pp. 93-106.

Cheung, C.M.Y., Sia, C.L. and Kuan, K.K. (2012), "Is this review believable? A study of factors affecting the credibility of online consumer reviews from an ELM perspective", Journal of the Association for Information Systems, Vol. 13 No. 8, pp. 6-18.

Chiang, J.K. and Suen, H. (2015), "Self-presentation and hiring recommendations in online communities: lessons from LinkedIn”, Computers in Human Behavior, Vol. 48, pp. 516-524.

Clark, L.A. and Roberts, S.J. (2010), "Employer's use of social networking sites: a socially irresponsible practice", Journal of Business Ethics, Vol. 95 No. 4, pp. 507-525.

Davison, H.K., Maraist, C. and Bing, M.N. (2011), "Friend or foe? The promise and pitfalls of using social networking sites for HR decisions", Journal of Business and Psychology, Vol. 26 No. 2, pp. 153-159.

de Zubielqui, D.C., Fryges, H. and Jones, J. (2017), "Social media, open innovation and HRM: implications for performance", Technological Forecasting and Social Change, Vol. 144, pp. 334-347.

DeKay, S. (2009), "Are business-oriented social networking web sites useful resources for locating passive jobseekers?”, Business Communication Quarterly, Vol. 72 No. 1, pp. 101-105.

Dellarocas, C., Gao, G. and Narayan, R. (2010), “Are consumers more likely to contribute online reviews for hit or niche products?”, Journal of Management Information Systems, Vol. 27 No. 2, pp. 127-158.

Dennis, C.M. (2011), "Legal implications of employee social media use", Massachusetts Law Review, Vol. 93 No. 4, pp. 380-396.

Dennis, A.R., Minas, R.K. and Lockwood, N.S. (2016), "Mapping the corporate blogosphere: linking audience, content, and management to blog visibility", Journal of the Association for Information Systems, Vol. 17 No. 3, pp. 16-24.

Dong, J.Q. and Wu, W. (2015), "Business value of social media technologies: evidence from online user innovation communities", The Journal of Strategic Information Systems, Vol. 24 No. 2, pp. 113-127.

Dou, Y., Niculescu, M.F. and Wu, D.J. (2013), "Engineering optimal network effects via social media features and seeding in markets for digital goods and services", Information Systems Research, Vol. 24 No. 1, pp. 164-185.

Drake, J., Hall, D., Brecton, B. and Posey, C. (2016), "Job applicants' information privacy protection responses: using social media for candidate screening", Ais Transactions on Human-Computer Interaction, Vol. 8 No. 4, pp. 160-184. 
Duffy, B.E. and Schwartz, B. (2018), "Digital women's work? job recruitment ads and the feminization of social media employment", New Media and Society, Vol. 20 No. 8, pp. 2972-2989.

Dwivedi, Y.K., Kapoor, K.K. and Chen, H. (2015), "Social media marketing and advertising", The Marketing Review, Vol. 15 No. 3, pp. 289-309.

Dwivedi, Y.K., Rana, N.P. and Alryalat, M. (2017), "Affiliate marketing: an overview and analysis of emerging literature”, The Marketing Review, Vol. 17 No. 1, pp. 33-50.

El-Ouirdi, M., El-Ouirdi, A., Segers, J. and Pais, I. (2016), "Technology adoption in employee recruitment: the case of social media in Central and Eastern Europe", Computers in Human Behavior, Vol. 57, pp. 240-249.

El-Ouirdi, M., Segers, J., El-Ouirdi, A. and Pais, I. (2015), "Predictors of job seekers' self-disclosure on social media", Computers in Human Behavior, Vol. 53, pp. 1-12.

Elzweig, B. and Peeples, D.K. (2009), "Using social networking web sites in hiring and retention decisions", Advanced Management Journal, pp. 27-35.

Esch, P. and Mente, M. (2018), "Marketing video-enabled social media as part of your erecruitment strategy: stop trying to be trendy", Journal of Retailing and Consumer Services, Vol. 44, pp. 266-273.

Fellnhofer, K. (2019), "Toward a taxonomy of entrepreneurship education research literature: a bibliometric mapping and visualization”, Educational Research Review, Vol. 27, pp. 28-55, doi: 10.1016/j.edurev.2018.10.002 (accessed 1 February 2021).

García-Crespo, Á., Colomo-Palacios, R., Gómez-Berbís, J.M. and Ruiz-Mezcua, B. (2010), "SEMO: a framework for customer social networks analysis based on semantics", Journal of Information Technology, Vol. 25 No. 2, pp. 178-188.

Gelinas, L., Robin Pierce, R., Sabune Winkler, S., Cohen, G., Lynch, H.F. and Bierer, B.E. (2017), "Using social media as a research recruitment tool: ethical issues and recommendations", The American Journal of Bioethics, Vol. 17 No. 3, pp. 3-14.

Gibbs, C., MacDonald, F. and MacKay, K. (2015), "Social media usage in hotel human resources: recruitment, hiring and communication", International Journal of Contemporary Hospitality Management, Vol. 27 No. 2, pp. 170-184.

Goes, P.B., Lin, M. and Au-Yeung, C.M. (2014), "'Popularity effect' in user-generated content: evidence from online product reviews", Information Systems Research, Vol. 25 No. 2, pp. 222-238.

Goh, K.Y., Heng, C.S. and Lin, Z. (2013), "Social media brand community and consumer behavior: quantifying the relative impact of user-and marketer-generated content", Information Systems Research, Vol. 24 No. 1, pp. 88-107.

Gu, L.L., Skierkowski, D., Florin, P., Friend, K. and Ye, Y. (2016), "Facebook, twitter, and Qr codes: an exploratory trial examining the feasibility of social media mechanisms for sample recruitment", Computers in Human Behavior, Vol. 60, pp. 56-96.

Haag, S. and Cummings, M. (2013), Management Information Systems for the Information Age, 9th ed., McGraw-Hill/Irwin, New York, NY.

Hauptmann, S. and Steger, T. (2013), "A brave new (digital) world? Effects of in-house social media on HRM", German Journal of Human Resource Management: Zeitschrift f\&\#252;r Personalforschung, Vol. 27 No. 1, pp. 26-46.

Hoek, J., O'Kane, P. and McCracken, M. (2016), "Publishing personal information online: how employers' access, observe and utilize social networking sites within selection procedures", Personnel Review, Vol. 45 No. 1, pp. 47-83.

Holland, P., Cooper, B.K. and Hecker, R. (2016), "Use of social media at work: a new form of employee voice?", The International Journal of Human Resource Management, Vol. 27 No. 21, pp. 2621-2634. 
Hosain, M.S. and Liu, P. (2020), “Social media recruitment on job candidates' perceptions: evidence from Bangladeshi fresh graduates", Postmodern Openings, Vol. 11 No. 1, pp. 20-41.

Hosain, M.S., Hossin, M.A., Xiaohua, Y., Aktaruzzaman, M. and Mustafi, M.A.A. (2020), "Social networking information and pre-employment background checks: the mediating role of sustainable organizational reputation", Sustainability, Vol. 12 No. 8, pp. 30-90.

Ismagilova, E., Dwivedi, Y.K., Slade, E.L. and Williams, M.D. (2017), Electronic Word of Mouth (eWOM) in the Marketing Context: A State of the Art Analysis and Future Directions, Springer International Publishing, Cham.

Jeske, D. and Shultz, K.S. (2015), "Using social media content for screening in recruitment and selection: pros and cons", Work, Employment and Society, Vol. 30 No. 3, pp. 535-546.

Jeske, D. and Shultz, K.S. (2019), "Social media screening and content effects: implications for job applicant reactions", International Journal of Manpower, Vol. 40 No. 1, pp. 73-86.

Jeske, D., Lippke, S. and Shultz, K.S. (2019), "Predicting self-disclosure in recruitment in the context of social media screening", Employee Responsibilities and Rights Journal, Vol. 31 No. 2, pp. 99-112.

Johnson, E.M. (2011), "Social media and labor and employment law: job applications and background checks, employee misconduct, ethical considerations", Paper presented at 2011 annual association law symposium, Washington, DC.

Kapoor, K.K., Dwivedi, Y.K. and Piercy, N. (2016), "Pay-per-click advertising: a review of literature", The Marketing Review, Vol. 16 No. 2, pp. 183-202.

Karoui, M., Dudezert, A. and Leidner, D.E. (2015), "Strategies and symbolism in the adoption of organizational social networking systems", The Journal of Strategic Information Systems, Vol. 24 No. 1, pp. 15-32.

Khan, Z., Yang, Y., Shafi, M. and Yang, R. (2019), "Role of social media marketing activities (SMMAs) in apparel brands customer response: a moderated mediation analysis", Sustainability, Vol. 11 No. 19 , pp. 51-67.

Khatri, C., Chapman, S.J., Glasbey, J., Kelly, M., Nepogodiev, D. and Bhangu, A. (2015), "Social media and internet driven study recruitment: evaluating a new model for promoting collaborator engagement and participation”, PLoS One, Vol. 10 No. 3, p. e0118899.

King, D.B., O'Rourke, N. and DeLongis, A. (2014), "Social media recruitment and online data collection: a beginner's guide and best practices for accessing low-prevalence and hard-to-reach populations", Canadian Psychology/Psychologie Canadienne, Vol. 55 No. 4, pp. 240-249.

Kissel, P. and Büttgen, M. (2015), "Using social media to communicate employer brand identity: the impact on corporate image and employer attractiveness", Journal of Brand Management, Vol. 22 No. 9, pp. 755-777.

Kluemper, D.H. (2013), "Social network screening: Pitfalls, possibilities, and parallels in employment selection", in Bondarouk, T. and Olivas-Lujan, M. (Eds), Advanced Series in Management, Emerald Group Publishing Ltd., Bingly, pp. 1-21.

Kluemper, D.H. and Rosen, P.A. (2009), "Future employment selection methods: evaluating social networking web sites", Journal of Managerial Psychology, Vol. 24 No. 6, pp. 567-580.

Kluemper, D.H., Rosen, P.A. and Mossholder, K.W. (2012), "Social networking websites, personality ratings, and the organizational context: more that meets the eye?", Journal of Applied Social Psychology, Vol. 42 No. 5, pp. 1143-1172.

Koch, T., Gerber, C. and De Klerk, J. (2018), "The impact of social media on recruitment: are you LinkedIn?", The Impact of Social Media on Recruitment: Are You LinkedIn? SA Journal of Human Resource Management, Vol. 16 No. 1, pp. 222-228.

Kucherov, D. and Zavyalova, E. (2012), "HRD practices and talent management in the companies with the employer brand", European Journal of Training and Development, Vol. 36 No. 1, pp. 86-104. 
Kumar, A. and Möller, K. (2018), "Extending the boundaries of corporate branding: an exploratory study of the influence of brand familiarity in recruitment practices through social media by B2B firms", Corporate Reputation Review, Vol. 21 No. 3, pp. 101-114.

Labrecque, L.I., Vor Dem Esche, J., Mathwick, C., Novak, T.P. and Hofacker, C.F. (2013), “Consumer power: evolution in the digital age”, Journal of Interactive Marketing, Vol. 27 No. 4, pp. 257-269.

Ladkin, A. and Buhalis, D. (2016), "Online and social media recruitment: hospitality employer and prospective employee considerations", International Journal of Contemporary Hospitality Management, Vol. 28 No. 2, pp. 327-345.

Lee, K., Lee, B. and Oh, W. (2015), "Thumbs up, sales up? The contingent effect of Facebook likes on sales performance in social commerce", Journal of Management Information Systems, Vol. 32 No. 4, pp. 109-143.

Leekha, C.N. and Sharma, S. (2014), "Employer branding: strategy for improving employer attractiveness", International Journal of Organizational Analysis, Vol. 22 No. 1, pp. $48-60$.

Lepistö, L. and Ihantola, E.M. (2018), "Understanding the recruitment and selection processes of management accountants: an explorative study", Qualitative Research in Accounting and Management, Vol. 15 No. 1, pp. 104-123.

Lieber, L.D. (2011), "Social media in the workplace-proactive protections for employers", Employment Relations Today, Vol. 38 No. 3, pp. 93-101.

Lister, M. (2017), "40 Essential social media marketing statistics for 2017", available at: www. wordstream.com/blog/ws/2017/01/05/social-media-marketing-statistics (accessed 22 June 2017).

Lorenz, B. and Kikkas, K. (2014), "If I do not like your online profile I will not hire you!", International Conference on Learning and Collaboration Technologies, Springer, pp. 429-439.

Lu, B., Guo, X., Luo, N. and Chen, G. (2015), "Corporate blogging and job performance: effects of workrelated and non work-related participation", Journal of Management Information Systems, Vol. 32 No. 4, pp. 285-314.

Ludvík, E., Mičík, M. and Petr, R. (2018), "Employer branding on social media and recruitment websites: symbolic traits of an ideal employer", E + M Ekonomie a Management, Vol. 21 No. 1, pp. 224-237.

Luo, X. and Zhang, J. (2013), "How do consumer buzz and traffic in social media marketing predict the value of the firm?", Journal of Management Information Systems, Vol. 30 No. 2, pp. 213-238.

McCarthy, J.M., Bauer, T.N., Truxillo, D.M., Anderson, N.R., Costa, A.C. and Ahmed, S.M. (2017), "Applicant perspectives during selection: a review addressing 'so what?', 'what's new?' and where to next?”, Journal of Management, Vol. 43 No. 6, pp. 1693-1717.

McFarland, L.A. and Ployhart, R.E. (2015), "Social media: a contextual framework to guide research and practice", Journal of Applied Psychology, Vol. 100 No. 6, pp. 1653-1677.

McRobert, C.J., Hill, J.C., Smale, T., Hay, E.M. and Windt, D.A. (2018), “A multi-modal recruitment strategy using social media and internet-mediated methods to recruit a multidisciplinary, international sample of clinicians to an online research study", PLoS One, Vol. 13 No. 7, p. e0200184.

Madera, J.M. (2012), "Using social networking websites as a selection tool: the role of selection process fairness and job pursuit intentions", International Journal of Hospitality Management, Vol. 31 No. 4, pp. 1276-1282.

Madia, S.A. (2011), "Best practices for using social media as a recruitment strategy", Strategic HR Review, Vol. 10 No. 6, pp. 19-24.

Marie-Cecile, C. and Pamela, L. (2017), “When employees don't 'like' their employers on social media”, MIT Sloan Management Review, Vol. 58 No. 2, pp. 63-70.

Melanthiou, Y., Pavlou, F. and Constantinou, E. (2015), "The use of social network sites as an erecruitment tool”, Journal of Transnational Management, Vol. 20 No. 1, pp. 31-49. 
Muduli, A. and Trivedi, JJ. (2020), "Social media recruitment: the role of credibility and satisfaction", Evidence-Based HRM: a Global Forum for Empirical Scholarship, Vol. 8 No. 2, pp. 237-251.

Neill, M.S. and Moody, M. (2015), "Who is responsible for what? Examining strategic roles in social media management", Public Relations Review, Vol. 41 No. 1, pp. 109-118.

Nessler, M. (2014), "Three ways virtual technologies are making a difference in HR", Employment Relations Today, Vol. 40 No. 4, pp. 47-52.

Nikolaou, I. (2014), "Social networking web sites in job search and employee recruitment", International Journal of Selection and Assessment, Vol. 22 No. 2, pp. 179-189.

Ollington, N., Gibb, J. and Harcourt, M. (2013), "Online social networks: an emergent recruiter tool for attracting and screening", Personnel Review, Vol. 42 No. 3, pp. 1-10.

Paltrinieri, A., Hassan, M.K., Bhaoo, S. and Khan, A. (2019), "A bibliometric review of sukuk literature”, International Review of Economics and Finance, in Press, doi: 10.1016/j.iref.2019.04.004.

Penelope, A.A. and Ashwini, L. (2014), "Who's googled whom? Trainees' internet and online social networking experiences, behaviors, and attitudes with clients and supervisors", Training and Education in Professional Psychology, Vol. 8 No. 2, pp. 105-111.

Petre, A., Osoian, C. and Zaharie, M. (2016), "Applicants' perceptions on online recruitment", Managerial Challenges of the Contemporary Society, Vol. 9 No. 1, pp. 63-67.

Pew Research Center (2018), "Social media use continues to rise in developing counties but plateaus across developed ones", available at: www.pewglobal.org/2018/06/19/social-media-use-continues-to-rise-indeveloping-countries-but-plateaus-across-developed-ones/pg_2018-06-19_global-tech_0-04/ (accessed 25 July 2020)

Pike, J.C., Bateman, P.J. and Butler, B.S. (2014), "Information from social networking sites: context collapse and ambiguity in hiring process", Information Systems Journal, Vol. 28 No. 4, pp. 729-758.

Priyadarshini, C., Kumar, Y. and Jha, R.R. (2017), "Employer attractiveness through social media: a phenomenological study”, The Qualitative Report, Vol. 22 No. 4, pp. 969-983.

Rahman, M., Isa, C.R., Tu, Y., Sarker, M.M. and Masud, M.A.K. (2020), "A bibliometric analysis of socially responsible investment Sukuk literature", Asian Journal of Sustainability and Social Responsibility, Vol. 5 No. 1, pp. 1-19, doi: 10.1186/s41180-020-00035-2.

Ramon, S.C., Rodríguez-Rivas, C., Vidal, S., Escabrós, M. and Oberst, U. (2017), "Interpersonal perception of LinkedIn profiles and employability”, Aloma: Journal of Psychology, Educational Sciences and Sports, Vol. 35 No. 2, pp. 13-22.

Roberts, G. and Sambrook, S. (2014), "Social networking and HRD", Human Resource Development International, Vol. 17 No. 5, pp. 577-587.

Rosoiu, O. and Popescu, C. (2016), "E-recruiting platforms: features that influence the efficiency of online recruitment systems", Informatica Economica, Vol. 20 No. 2, pp. 46-56.

Roth, P.L., Bobko, P., Van Iddekinge, C.H. and Thatcher, J.B. (2013), "Social media in employeeselection-related decisions: a research agenda for uncharted territory", Journal of Management, Vol. 20 No. 10, pp. 269-298.

Roulin, N. and Bangerter, A. (2013), "Social networking websites in personnel selection: a signaling perspective on recruiters' and applicants' perceptions", Journal of Personnel Psychology, Vol. 12 No. 3, pp. 143-157.

Roulin, N. and Levashina, J. (2018), "LinkedIn as a new selection method: psychometric properties and assessment approach”, Personnel Psychology, Vol. 72, pp. 322-331.

Saini, G.K., Gopal, A. and Kumari, N. (2015), "Employer brand and job application decisions: insights from the best employers", Management and Labour Studies, Vol. 40 Nos 1/2, pp. 34-51.

Sameen, S. and Cornelius, S. (2013), "Social networking sites and hiring: how social media profiles influence hiring decisions", Journal of Business Studies Quarterly, Vol. 7 No. 1, pp. 12-23. 
Segal, J.A. (2014), "The law and social media in hiring", HR Magazine, Vol. 59, pp. 70-72.

Sharma, A. and Bhatnagar, J. (2016), "Enterprise social media at work: web-based solutions for employee engagement”, Human Resource Management International Digest, Vol. 24 No. 7, pp. 16-19.

Sivertzen, A.M., Nilsen, E.R. and Olafsen, A.H. (2013), "Employer branding: employer attractiveness and the use of social media", Journal of Product and Brand Management, Vol. 22 No. 7, pp. 473-483.

Slovensky, R. and Ross, W.H. (2012), "Should human resource managers use social media to screen job applicants? Managerial and legal issues in the USA", info, Vol. 14 No. 1, pp. 55-69.

Smith, W.P. and Kidder, D.L. (2010), "You've been tagged! (then again, maybe not): employers and Facebook”, Business Horizons, Vol. 53 No. 5, pp. 491-499.

Spellmann, E. (2018), "How to leverage social media to benefit your business", Paper presented at Ranger College Erath County, Stephenville, TX.

Stoughton, J.W., Thompson, L.F. and Meade, A.W. (2015), "Examining applicant reactions to the use of social networking websites in pre-employment screening", Journal of Business and Psychology, Vol. 30 No. 1, pp. 73-88.

Suen, H. (2018), "How passive job candidates respond to social networking site screening", Computers in Human Behavior, Vol. 85, pp. 396-404.

Take the Work Out of Hiring (2017), "Facebook to add new features for employers", available at: www. facebook.com/business/news/take-the-work-out-of-hiring (accessed 25 June 2020).

Tanwar, K. and Prasad, A. (2017), "Employer brand scale development and validation: a second-order factor approach", Personnel Review, Vol. 46 No. 2, pp. 389-409.

Thomas, S.L., Rothschild, P.C. and Donegan, C. (2015), "Social networking, management responsibilities, and employee rights: the evolving role of social networking in employment decisions", Employee Responsibilities and Rights Journal, Vol. 27 No. 4, pp. 307-323.

Tripathy, M.R. and Kaur, T. (2012), "Perceptions of employees on information checks by employers using social networking sites in IT sector", Management and Labour Studies, Vol. 37 No. 4, pp. 345-358.

van Eck, N.J. and Waltman, L. (2014), "Visualizing bibliometric networks", in Ding, Y., Rousseau R., Wolfram, D. (Eds), Measuring Scholarly Impact: methods and Practice, Springer International Publishing, Cham, pp. 285-320.

Van-Iddekinge, C.H., Lanivich, S.E., Roth, P.L. and Junco, E. (2016), "Social media for selection? Validity and adverse impact potential of a Facebook-based assessment", Journal of Management, Vol. 42 No. 7, pp. 1811-1835.

Vidros, S., Kolias, C. and Kambourakis, G. (2016), "Online recruitment services: another playground for fraudsters”, Computer Fraud and Security, Vol. 3, pp. 8-13.

Villeda, M. and McCamey, R. (2019), "Use of social networking sites for recruiting and selecting in the hiring process", International Business Research, Vol. 12 No. 3, pp. 66-78.

Waltman, L. and van Eck, N.J. (2013), "A smart local moving algorithm for large-scale modularitybased community detection”, European Physical Journal, Vol. 86 No. 11, pp. 471, doi: 10.1140/ epjb/e2013-40829-0 (accessed 1 February 2021).

Waring, R.L. and Buchanan, F.R. (2010), "Social networking web sites: the legal and ethical aspects of pre-employment screening and employee surveillance", Journal of Human Resources Education, Vol. 4 No. 2, pp. 14-23.

Wehner, B., Ritter, C. and Leist, S. (2017), "Enterprise social networks: a literature review and research agenda”, Computer Networks, Vol. 114, pp. 125-142. 
Willey, L., White, B.J., Domagalski, T. and Ford, J.C. (2012), "Candidate screening, information technology and the law: social media considerations", Issues in Information Systems, Vol. 13 No. 1, pp. 300-309.

Wolk, D. (2004), "Social networking sites pique the interest of company recruiters", Workforce Management [e-Journal], Vol. 83, pp. 70-73.

Yarbrough, J.R. (2018), "Is cybervetting ethical? An overview of legal and ethical issues", Journal of Ethical and Legal Issues, Vol. 11, pp. 1-23.

Yaseen, Z.K. and Yussef, M. (2016), "The influence of social media on recruitment and selection process in SMEs", Journal of Small Business and Entrepreneurship Development, Vol. 4 No. 2, pp. 21-27.

Zide, J., Elman, B. and Shahani-Denning, C. (2014), "LinkedIn and recruitment: how profiles differ across occupations”, Employee Relations, Vol. 36 No. 5, pp. 583-604.

\section{Corresponding author}

Md Sajjad Hosain can be contacted at: sajjad_hosain@yahoo.com

For instructions on how to order reprints of this article, please visit our website: 